\title{
ANALISIS PERAN PUBLIC RELATIONS DALAM MEMBENTUK CITRA HOTEL RA PREMIERE SIMATUPANG MELALUI KAMPANYE "WE ACT”
}

\author{
Febrilian Aulia Sukmananda, Sri Tunggul Panindriya \\ Institut Komunikasi dan Bisnis LSPR
}

\begin{abstract}
The hotel industry is now experiencing a significant increase. One of the newly established hotels in 2017 with the concept of "eco friendly hotel" is Ra Premiere Simatupang Hotel. The researcher analyzes The Role of Public Relations in shaping the image of Ra Premiere Simatupang Hotel Through "We Act" Campaign. Using interview supplemented with secondary data from previous research, archives, and news related to the research topic uses descriptive qualitative methods. This research was conducted to determine the role of public relations in shaping the image of Ra Premiere Simatupang Hotel in the eyes of the guests through the "We Act" Public Relations Campaign. This study also uses the theory of the role of public relations by Ruslan. By generating a role as a communicator, fostering relationships, as backup management, as a corporate image. The obstacles found by the public relations role is the lack of intensity towards internal parties. The results of the study show that public relations has an important role and has undergone its role in accordance with the theory used to shape the image of the Ra Premiere Simatupang Hotel. The contribution of this research is expected to add to the science of communication for researchers, especially regarding science in the formation of hotel images. Besides that, it can also add insight into the role of public relations.
\end{abstract}

\author{
Keywords \\ The Role of Public Relations, Image, \\ Indonesian Hospitality Industry, \\ Campaign \\ Correspondence Contact: \\ febrilianaulia@gmail.com
}

\section{PENDAHULUAN}

Pesatnya perkembangan dunia perhotelan di Indonesia saat ini membuat timbulnya persaingan yang sangat ketat di antara industri perhotelan. Kini hadirnya berbagai macam hotel-hotel baru juga saling berlomba-lomba menawarkan fasilitas dan kualitas pelayanan yang lengkap, dan harga yang sangat terjangkau dengan berbagai keunikan tersendiri yang ditawarkan oleh masing-masing pihak hotel. Di satu sisi hotel-hotel yang telah lebih dahulu menguasai pasar khususnya di kota pusat bisnis, yaitu DKI Jakarta diantaranya adalah Hotel Ra Premiere Simatupang Jakarta, harus bersiap-siap dalam menghadapi persaingan munculnya hotel-hotel low budget seperti Hotel Mercure Simatupang, Hotel Aston Simatupang dan hotel-hotel lainnya yang siap merebut pasar yang sebelumnya telah mereka kuasai lebih dahulu. (Haningtyas, 2018)

Dengan banyaknya hotel bintang di Simatupang, tentunya menjadikan adanya persaingan yang ketat serta tantangan untuk mendapatkan pelanggan yang akan menikmati fasilitas terbaik sebagai keunggulan dari masing-masing hotel. Untuk berada di posisi yang unggul dalam memenangkan persaingan di industri perhotelan, diperlukan adanya pemikiran dan implementasi dari perencanaan yang strategis supaya perusahaan dapat bertahan dalam persaingan bisnis. Inovasi pada bisnis merupakan hal efektif yang menjadikan perusahaan sukses dengan pendekatan inovasi yang berbeda dalam mendorong penciptaan sebuah nilai dan daya saing. (Ikeda, K., \& Marshall, 2016) 
Menurut riset BPS Jakarta (2018) menunjukan bahwa tingkat hunian hotel di seluruh Indonesia mencapai $58,75 \%$. Ini menunjukan bahwa rata-rata jumlah kamar yang digunakan setiap malam pada seluruh hotel di Indonesia selama tahun 2018 sebesar 58,75\% dari jumlah kamar yang tersedia. Angka tersebut lebih tinggi 2,06\% jika dibandingkan dengan kondisi tingkat hunian hotel pada tahun 2017 yang hanya 56,69\%. Hotel Ra Premiere Simatupang Jakarta adalah salah satu hotel bintang empat yang terletak di Jakarta Selatan dan sudah berdiri sejak November 2017. Hotel Ra Premiere Simatupang - Jakarta didirikan oleh Rendra I. Lembong, hotel ini berbeda dengan hotel pada umumnya yakni hotel yang dikenal sebagai hotel bisnis dengan interior layaknya sebuah apartment dan bernuansa hijau. (Data internal Ra Premiere Simatupang, 2017).

Isu-isu global pada pengelolaan lingkungan merupakan perhatian yang cukup serius pada saat ini, demikian pula masih sedikitnya industri perhotelan di Jakarta yang berkomitmen terhadap ramah lingkungan sehingga dibutuhkannya investigasi ilmiah yang bertujuan untuk menganalisis praktik pengelolaan produk hotel dengan ramah lingkungan yang di sebut dengan Green Hotel dalam rangka peningkatan efisiensi energi, efisiensi air, kualitas udara, dan sistem pengelolaan limbah padat dan limbah cair. (Roedji, 2016)

Data keseluruhan bangunan termasuk di dalamnya bangunan hotel, menggunakan 50\% energi secara umum atau $70 \%$ listrik dari total konsumsi di Indonesia, menjadikannya sebagai pengguna energi terbesar bahkan melebihi sektor industri dan transportasi. (Kencana, B., Agustina, I., Panjaitan, R., \& Sulistiyanto, 2015). Besarnya konsumsi energi pada bangunan hotel dapat berkontribusi terhadap emisi gas rumah kaca dan pemanasan global yang cukup tinggi. Penghematan energi menjadi salah satu solusi cerdas untuk diaplikasikan pada bangunan, terutama bangunan hotel.

Dalam acara National Green Hotel Award 2011 menurut Kementerian Pariwisata dan Ekonomi Kreatif dalam Supriadi (2016) menunjukan bahwa, tidak banyak hotel di Indonesia yang berkomitmen terhadap ramah lingkungan. Karena kurangnya pemahaman terhadap green hotel itu sendiri, yakni hotel yang memiliki konsep untuk mempraktikkan kesadaran terhadap kualitas lingkungan, hal ini jika terus dibiarkan dapat berakibat buruk terhadap lingkungan atau jalannya sustainable development (pembangunan berkelanjutan).

Meskipun belum sepenuhnya hotel-hotel yang ada di Jakarta mendapatkan sertifikasi sebagai green hotel setidaknya masing-masing hotel mulai mencoba untuk berpikir mengenai konsepkonsep ramah lingkungan. Apabila suatu hotel peduli pada lingkungannya, otomatis juga peduli pada tamunya. Seperti pada hotel Ra Premiere Simatupang yang sedang menjalankan pemahaman terhadap green hotel tersebut. (Supriadi, 2016)

Dari penjelasan diatas, maka fenomena dibalik terciptanya citra positif suatu perusahaan seperti hotel sangatlah menarik untuk diteliti. Salah satu cara efektif dalam penyampaian pesan-pesan perusahaan kepada publiknya melalui kampanye public relations yang terarah. Kampanye public relations yang terarah dapat diwujudkan apabila public relations memiliki perencanaan kampanye public relations yang tepat.

Kampanye merupakan salah satu bentuk kegiatan komunikasi yang dilakukan secara terencana untuk menciptakan dampak tertentu terhadap publik. Kegiatan tersebut umumnya diselenggarakan oleh suatu lembaga baik pemerintah maupun swasta. Suatu kegiatan kampanye dimaksudkan untuk mensosialisasikan suatu program, aktivitas dan informasi tertentu; memperkenalkan sesuatu; meningkatkan kesadaran dan mencari dukungan publik; serta untuk mempengaruhi dan membujuk publik. (Daud, R. F., \& Apriliani, 2017) 
Pelaksanaan kampanye public relations lebih ditekankan melalui teknik persuasif dan edukatif, untuk mengubah perilaku, sikap, tanggapan, persepsi, hingga membentuk opini publik yang positif dengan cara yang efektif. (Amalya, 2015)

Hotel Ra Premiere Simatupang masih terus melanjutkan komitmennya sebagai eco green hotel dalam menjalankan konservasi ramah lingkungan. Melalui kampanyenya yaitu "We Act", Ra Premiere Simatupang berharap supaya dapat mengedukasi dan membuat kesadaran lebih kepada tamu mengenai pentingnya kampanye tersebut, dan juga sebagai bentuk dukungan dalam menjaga kualitas lingkungan saat ini.

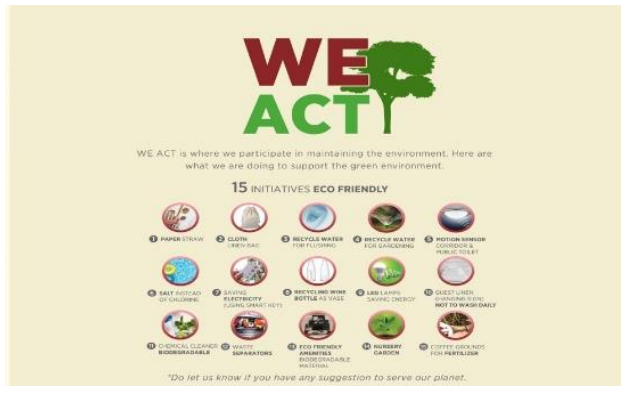

Kampanye "We Act" 15 initiatives eco friendly Hotel Ra Premiere Simatupang, 2017

Hotel Ra Premiere Simatupang memulai kampanye "We Act" tersebut melalui 15 initiatives eco friendly-nya, diantaranya meliputi menggunakan paperstraw, menyediakan cloth line-in bag, menggunakan motion sensor di koridor dan di public toilet, fasilitas kolam renang yang dilengkapi dengan garam tidak dengan bahan-bahan kimia yang berbahaya seperti klorin sehingga aman untuk tamu yang memiliki kulit sensitif, memakai air daur ulang untuk berkebun, menggunakan smartkey sebagai bentuk penghematan listrik, menggunakan lampu LED untuk penghematan energi, menggunakan botol wine bekas sebagai vas bunga di ruang kamar, terdapat guest linen changing sign yaitu untuk tidak mencuci setiap hari, membersihkan lantai dengan menggunakan chemical cleaner biodegradable, menggunakan waste separators atau pemisah limbah, menggunakan eco friendly amenities dengan bahan biodegradable, melakukan nursery garden, menggunakan ampas kopi sebagai pupuk, tidak menggunakan botol plastik di tiap-tiap kamar, hingga menggunakan air daur ulang untuk flushing di tiap-tiap toilet.

Kampanye "We Act" merupakan suatu bentuk program yang dijalankan oleh Hotel Ra Premiere Simatupang dimana dalam komunikasi kampanye mengandung pesan himbauan atau ajakan yang tujuannya menumbuhkan kesadaran masyarakat terhadap kepedulian akan lingkungan. Melalui kampanye "We Act" tersebut Hotel Ra Premiere Simatupang ingin membentuk citranya sebagai hotel yang ramah lingkungan (green hotel) dan mempraktikkan penghematan energi.

Selain Hotel Ra Premiere Simatupang, terdapat juga beberapa hotel lain yang juga menjalankan praktik penghematan energi diantaranya seperti Hotel Mercure Simatupang. Konsep yang digunakan oleh public relations Hotel Mercure Simatupang yaitu dengan melalui "Planet 21" Program yang dimilikinya. "Planet 21" merupakan sebuah program menyeluruh yang berhubungan dengan lingkungan hidup dan sosial kemasyarakatan sebagai bagian penting dari strategi bisnis Accor di seluruh dunia. Program ini kembali menegaskan 21 komitmen dan tujuan Accor Hotel untuk dicapai pada tahun 2015. (Data internal Accor Hotel, 2015) 
Graci \& Doods ( dalam Sinangjoyo, 2013) menyatakan bahwa green hotel merupakan salah satu bagian dari green tourism product sedangkan green tourism merupakan komponen dari sustainable tourism yang didefinisikan sebagai kegiatan perjalanan untuk mewujudkan keberkelanjutan dengan melestarikan sumber daya alam, melestarikan budaya serta memberikan sumbangan pada sektor ekonomi.

Berdasarkan Undang-Undang Pariwisata nomor 10 tahun 2009 (dalam Keuangan, n.d.) menuliskan bahwa setiap pengusaha pariwisata berkewajiban untuk memelihara lingkungan yang sehat, bersih, asri serta memelihara kelestarian lingkungan alam dan budaya. Salah satu usaha jasa wisata yang memiliki peranan penting dalam investasi pembangunan kepariwisataan nasional ialah hotel, sedangkan yang dimaksud dengan green hotel yaitu hotel yang memiliki sifat ramah lingkungan dengan program penghematan sumber daya alam, energi dan mengurangi hasil limbah.

Berkat dukungan yang diterima dari tamu, karyawan hingga pemilik hotel baik dukungan secara langsung maupun melalui media sosial Instagram dengan memosting keunggulankeunggulan yang dimiliki oleh Hotel Ra Premiere Simatupang, idealnya Hotel Ra Premiere Simatupang dapat lebih maju dibandingkan hotel biasa karena memiliki faktor pembeda dan keunikan tersendiri jika dibandingkan dengan hotel-hotel lain yang ada di Jakarta. Proses komunikasi kepada masyarakat melalui publikasi yang ada, diharapkan agar masyarakat dapat lebih mengetahui kampanye ini dan semakin banyak masyarakat yang ikut berpartisipasi dalam menjalankan kampanye public relations "We Act" ini, sehingga dapat lebih membentuk citra dari Hotel Ra Premiere Simatupang saat ini.

Berdasarkan identifikasi dan batasan masalah, maka rumusan masalah adalah sebagai berikut "bagaimana peran public relations dalam membentuk citra Hotel Ra Premiere Simatupang melalui kampanye "We Act" ?"

Tujuan dari penelitian ini adalah; (1) untuk menganalisa peran public relations dalam membentuk citra Hotel Ra Premiere Simatupang melalui kampanye "We Act", (2) untuk menganalisa hambatan-hambatan dalam implementasi peran public relations yang dilakukan dalam membentuk citra Hotel Ra Premiere Simatupang melalui kampanye "We Act", (3) untuk mengetahui upaya yang dilakukan dalam mengatasi hambatan dalam implementasi peran public relations yang dilakukan dalam membentuk citra Hotel Ra Premiere Simatupang melalui kampanye "We Act".

Hasil dari penelitian ini diharapkan dapat memiliki manfaat akademis dan manfaat praktis. Manfaat akademis diharapkan penelitian ini dapat menambah ilmu komunikasi untuk para peneliti, khususnya mengenai ilmu pengetahuan dalam pembentukan citra hotel. Selain itu juga dapat menambah wawasan mengenai peran public relations. Sedangkan manfaat praktis bagi Hotel Ra Premiere Simatupang dalam menambah referensi untuk mengembangkan peran public relations-nya dalam membentuk citra hotel dan bagi masyarakat luas sebagai tambahan informasi pembaca yang mempunyai masalah penelitian yang sama atau ingin melakukan penelitian yang lebih dalam.

Kampanye public relations perlu disertai proses manajemen tertentu supaya sesuai dengan tujuannya. Berdasarkan konsep peran public relations menurut Ruslan (2016) dikutip dalam bukunya yang berjudul "Manajemen Public Relations dan Media Komunikasi”, peran public relations terdiri dari communicator, relationship, back up management dan good image maker.

Menurut IPRA/International Public Relations Association (dalam Ardianto, 2011) mendefinisikan public relations sebagai fungsi manajemen dari ciri-ciri yang terencana dan 
berkelanjutan melalui organisasi dan lembaga swasta atau negara untuk memperoleh, simpati dan dukungan dari mereka yang terkait atau mungkin ada hubungannya dengan penelitian opini publik di antara mereka.

Menurut Ross (dalam Venus, 2018, p.9) kampanye public relations bertujuan untuk membangun citra atau reputasi organisasi, mengatasi krisis organisasi, serta membentuk saling pengertian antara organisasi dan publiknya.

Menurut Pfau dan Parrot (dalam Venus, 2018, p.10) menyebutkan tiga istilah efek dalam kampanye yang dapat mencapai khalayak sasaran kampanye, yakni sebagai berikut : (1) Awareness, dalam tahap ini biasanya para khalayak diarahkan untuk dapat menciptakan perubahan pada pengetahuan yang telah mereka miliki. Pengaruh yang diharapkan dalam tahapan awareness ini adalah munculnya kesadaran, berubahnya keyakinan atau meningkatnya pengetahuan para khalayak mengenai isu yang diangkat pada kampanye. (2) Attitude, tahapan dimana khalayak diarahkan pada perubahan sikap, sasarannya adalah untuk menumbuhkan rasa simpati, rasa suka, kepedulian atau keberpihakan khalayak terhadap isuisu yang menjadi tema kampanye. (3) Action, pada tahapan terakhir ini, khalayak diarahkan untuk mengubah perilaku secara konkret dan terukur. Tahap ini menghendaki adanya tindakan tertentu yang dilakukan oleh sasaran kampanye, namun tindakan tersebut dapat bersifat sesekali saja atau berkelanjutan.

Menurut Jefkins (dalam Soemirat, S. \& Ardianto, 2012, p.117) mengklasifikasikan jenis-jenis citra diantaranya : (1) Mirror Image (citra bayangan), bagaimana dugaan (citra) manajemen terhadap publik eksternal dalam melihat perusahaannya. (2) Current Image (citra masih hangat), merupakan kebalikan dari citra bayangan atau pandangan yang dianut oleh pihakpihak luar mengenai suatu organisasi atau perusahaan. (3) Wish Image (citra yang diharapkan), yakni manajemen mengharapkan pencapaian prestasi tertentu. Citra ini diaplikasikan untuk sesuatu yang baru sebelum publik eksternal mendapatkan informasi secara lengkap. (4) Multiple Image (citra yang berlapis), yaitu sejumlah individu, kantor cabang, atau perwakilan perusahaan lainnya dapat membentuk citra tertentu yang belum tentu sesuai dengan keseragaman citra seluruh organisasi atau perusahaan.

Proses pembentukan citra menurut Soemirat \& Ardianto (2012) dalam buku yang berjudul "Dasar-dasar Public Relations". Citra dapat terbentuk berdasarkan pengetahuan dan informasi-informasi yang diterima seseorang. Komunikasi tidak secara langsung menimbulkan perilaku tertentu, tetapi cenderung mempengaruhi cara kita mengorganisasikan citra kita kepada lingkungan.

Proses pembentukan citra yang sesuai dengan pengertian sistem komunikasi dalam struktur kognitif yang dijelaskan oleh Nimpoeno (dalam Soemirat, S. \& Ardianto, 2012) dalam laporan penelitian mengenai Tingkah Laku Konsumen adalah sebagai berikut :

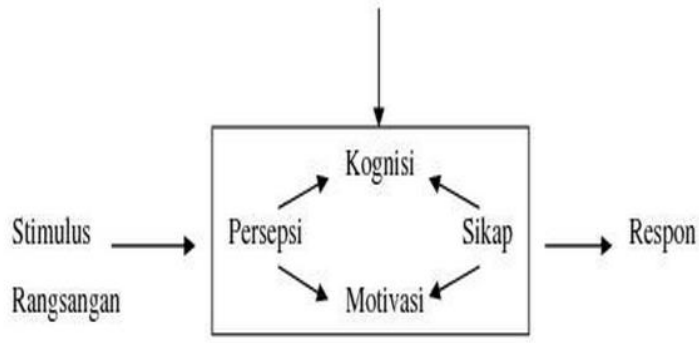

Model Pembentukan Citra, dari Soemirat \& Ardianto, 2012 
Menurut Lipman (dalam Soemirat, S. \& Ardianto, 2012) menyatakan bahwa ke-empat komponen tersebut yaitu persepsi - kognisi - motivasi - sikap dapat diartikan sebagai citra individu terhadap rangsang. Ini juga disebut sebagai "picture in our head".

Persepsi dapat diartikan sebagai hasil pengamatan terhadap unsur lingkungan yang dihubungkan dengan suatu proses pemaknaan. Dengan kata lain, individu akan memberikan makna terhadap rangsang berdasarkan pengalamannya mengenai rangsang. Kemampuan mempersepsi itulah yang dapat melanjutkan proses pembentukan citra. Persepsi atau pandangan individu akan positif apabila informasi yang diberikan oleh rangsang dapat memenuhi kognisi individu.

Kognisi merupakan suatu keyakinan diri dari individu terhadap stimulus. Keyakinan ini akan timbul jika individu telah mengerti rangsang tersebut, sehingga individu harus diberikan informasi-informasi yang cukup yang dapat mempengaruhi perkembangan kognisinya. Motivasi dan sikap yang ada akan menggerakkan respons seperti yang diinginkan oleh pemberi rangsang.

Motif merupakan keadaan dalam pribadi seseorang yang mendorong keinginan individu untuk melakukan kegiatan-kegiatan tertentu guna mencapai suatu tujuan. Sikap merupakan kecenderungan bertindak, berpersepsi, berpikir, dan merasa dalam menghadapi objek, ide, situasi atau nilai. (Soemirat, S. \& Ardianto, 2012)

Peran public relations sangatlah penting dalam berlangsungnya suatu kampanye untuk membangun citra Hotel Ra Premiere Simatupang - Jakarta, oleh sebab itu berdasarkan latar belakang yang sudah disampaikan dibuatlah penelitian "Peran Public Relations dalam Membentuk Citra Hotel Ra Premiere Simatupang Melalui Kampanye “We Act”".

\section{METODOLOGI PENELITIAN}

Metode yang digunakan oleh peneliti dalam melakukan penelitian ini adalah melalui pendekatan deskriptif kualitatif. Dalam penelitian sosial, masalah penelitian, tema dan topik baik secara substansi dan konten berbeda dengan metode kuantitatif. Menurut Cresswell (dalam Ardianto, 2016, p.61), metode deskriptif kualitatif termasuk dalam paradigma penelitian post-positivistik. Dalam hal ini, yang menjadi asumsi dasar dalam penelitian postpositivistik adalah; Pengetahuan bersifat konjektual dan tidak berlandaskan apapun. Kita tidak pernah mendapatkan kebenaran yang bersifat absolute. Penelitian merupakan proses membuat klaim-klaim, kemudian menyaring sebagian klaim tersebut menjadi klaim-klaim lain yang kebenarannya jauh lebih kuat. Pengetahuan dibentuk oleh data, bukti dan pertimbangan logis. Dalam praktiknya, peneliti mengumpulkan informasi dengan menggunakan instrumen pengukuran tertentu yang diisi oleh partisipan atau dengan melakukan observasi mendalam di lokasi penelitian. Memiliki waktu luang untuk diwawancarai oleh peneliti, sebab proses wawancara menyita cukup banyak waktu. Informan terbiasa menerapkan teori budaya masyarakat lokal atau akal sehat pragmatis, ini bukanlah tipe analisis yang memandang dari perspektif pendidikan atau yang terpengaruh oleh media.

Dalam hal penelitian saat ini, peneliti menggunakan teknik pemeriksa keterpercayaan yang menggunakan triangulasi sumber, peneliti menggunakan wawancara sebagai teknik pengumpulan data dengan mewawancarai sumber yang berbeda. Sumber yang digunakan oleh peneliti yakni adalah pihak internal dari Hotel Ra Premiere Simatupang divisi Public Relations, Chief Operating Officer Hotel Ra Premiere Simatupang, dan pihak eksternal yaitu tamu dari Hotel Ra Premiere Simatupang. 


\section{HASIL DAN PEMBAHASAN}

Setiap perusahaan yang menawarkan produk berupa jasa dan barang tentunya memiliki visi dan misi tersendiri agar bergeraknya perusahaan tersebut terarah dan mengacu pada visi dan misi perusahaan tersebut, tidak terlepas dari Hotel Ra Premiere Simatupang yang juga memiliki ketertarikan dan loyalitas dalam melayani tamunya juga memiliki visi dan misi tersendiri yang tak telak ditelan zaman.

Visi dari Hotel Ra Premiere Simatupang menjadi hotel terkemuka di Jakarta Selatan dengan layanan dan produk yang berkualitas tinggi. Misi hotel ini diantaranya adalah untuk mengoptimalkan kepuasan tamu melalui team yang professional, mempertahankan tamu untuk kembali, mengembalikan investasi pemilik, dan mendukung ekspansi perusahaan.

Hotel Ra Premiere Simatupang masih terus melanjutkan komitmennya sebagai eco green hotel dalam menjalankan konservasi ramah lingkungan. Melalui kampanyenya yaitu "We Act", Ra Premiere Simatupang berharap supaya dapat mengedukasi dan membuat kesadaran lebih kepada tamu mengenai pentingnya kampanye tersebut, dan juga sebagai bentuk dukungan dalam menjaga kualitas lingkungan saat ini.

Menurut Handbook Hotel Ra Premiere Simatupang (2017) dalam company profile-nya dijelaskan bahwa Hotel Ra Premiere Simatupang didirikan oleh Rendra I. Lembong pada tahun 2017. Beliau merupakan seorang Insinyur dari Cornell University, yang bekerja di GE Singapura. Saat ini, beliau menjalankan bisnis propertinya sudah lebih dari 15 tahun pengalaman. Salah satunya ialah Hotel Ra Premiere Simatupang. Ra Premiere Simatupang merupakan hotel bintang empat yang berlokasi di TB Simatupang, sebuah kawasan bisnis baru di Jakarta Selatan. Hotel ini dikelilingi oleh banyak tempat menarik, seperti pusat perbelanjaan, kawasan bisnis, bar \& lounge, serta lapangan golf. Dengan lokasinya yang sangat strategis, hotel ini memiliki akses mudah menuju dan dari Bandar Udara Internasional Soekarno Hatta, yang membuat para tamu, terutama untuk para business travellers, merasa lebih nyaman.

Sebanyak 110 kamar yang ada di hotel ini terbagi menjadi beberapa tipe, antara lain deluxe, studio executive, executive suite, premiere suite, dan residence suite. Setiap kamarnya dilengkapi oleh TV kabel LED TV dengan satellite channel, akses Internet berkecepatan tinggi, AC, kitchen, coffee machines, washing machines, dish washer, telepon, brankas, bathtub, dan shower. Selain di tiap-tiap kamar, akses Internet Wi-Fi juga tersedia di area umum. Semua kamar dirancang khusus dengan tema minimalis modern guna menghadirkan suasana nyaman bagi para tamu. Khusus untuk business travellers, Ra Premiere Simatupang menyediakan sepuluh ruang pertemuan dengan fasilitas lengkap.

Untuk menunjang kenyamanan para tamu, Ra Premiere Simatupang menyediakan beberapa fasilitas, antara lain KOI Simatupang yang merupakan salah satu highlight dari Ra Premiere Simatupang. KOI Simatupang menyajikan berbagai hidangan lezat mulai masakan internasional hingga kuliner khas local. KOI Simatupang hanya beroperasi sampai jam 10 malam, melayanin prasmanan, menu ala carte, makanan ringan, dan berbagai minuman yang menyegarkan. Ra Premiere Simatupang juga menyediakan lounge, gym, spa, bar dan kolam renang untuk para tamu bersantai setelah menghabiskan hari-hari yang sibuk.

Ra Premiere Simatupang percaya pada keramahan dan kasih sayang, seperti semangat Ra Dewa Matahari di Mesir yang membawa cahaya, kehangatan, dan pertumbuhan. Karakter seperti itu dibawa ke pelanggan dalam bentuk layanan harian karena mereka menikmati hidup di Ra Premiere Simatupang. Visual utama dalam logo Ra Premiere Simatupang mewakili cahaya, kehangatan, dan pertumbuhan. 
Kurva diyakini paling mencerminkan perasaan hangat dan nyaman, karena terhubung dengan bentuk tubuh manusia yang tidak memiliki sudut sempit. Dari inspirasi itu, kurva pada logo Ra Premiere Simatupang dirancang untuk menggaungkan sambutan hangat dan layanan bisnis kepada pelanggannya. Tidak adanya garis-garis kaku dalam proyek logo karisma modern dan kontemporer Ra Premiere Simatupang.

Hotel Ra Premiere Simatupang memulai kampanye "We Act" melalui 15 initiatives eco friendly-nya, diantaranya meliputi menggunakan paperstraw, menyediakan cloth line-in bag, menggunakan motion sensor di koridor dan di public toilet, fasilitas kolam renang yang dilengkapi dengan garam tidak dengan bahan-bahan kimia yang berbahaya seperti klorin sehingga aman untuk tamu yang memiliki kulit sensitif, memakai air daur ulang untuk berkebun, menggunakan smartkey sebagai bentuk penghematan listrik, menggunakan lampu LED untuk penghematan energi, menggunakan botol wine bekas sebagai vas bunga di ruang kamar, terdapat guest linen changing sign yaitu untuk tidak mencuci setiap hari, membersihkan lantai dengan menggunakan chemical cleaner biodegradable, menggunakan waste separators atau pemisah limbah, menggunakan eco friendly amenities dengan bahan biodegradable, melakukan nursery garden, menggunakan ampas kopi sebagai pupuk, tidak menggunakan botol plastik di tiap-tiap kamar, hingga menggunakan air daur ulang untuk flushing di tiap-tiap toilet.

Kampanye "We Act" merupakan suatu bentuk program yang dijalankan oleh Hotel Ra Premiere Simatupang dimana dalam komunikasi kampanye mengandung pesan himbauan atau ajakan yang tujuannya menumbuhkan kesadaran masyarakat terhadap kepedulian akan lingkungan. Melalui kampanye "We Act" tersebut Hotel Ra Premiere Simatupang ingin membentuk citranya sebagai hotel yang ramah lingkungan (green hotel) dan mempraktikkan penghematan energi.

Dalam cara menganalisis hasil penelitian, peneliti saat ini mengacu pada teori peran Public Relations yang ditulis oleh Rosady Ruslan di buku Manajemen Public Relations dan Media Komunikasi: Konsepsi dan Aplikasi Edisi Revisi (2016, p.26) yakni sebagai berikut :

\section{Sebagai Communicator.}

Divisi Public Relations di Hotel Ra Premiere Simatupang berperan sebagai perwakilan perusahaan, dalam melakukan komunikasi dengan publik internal dan komunikasi dengan publik eksternal (Ruslan, 2016, p.26) "Peran PR dalam kampanye “We Act” ini cukup penting. PR dalam hal ini adalah membuat bagaimana Ra Premiere Simatupang Hotel dapat membangun citra nya sebagai Eco Hotel. Apa saja yang perlu dilakukan? Exposure/Publikasi. Bentuk publikasi yang kami lakukan adalah, pertama sosialisasikan mengenai We Act ini kepada semua staff yang bekerja, agar semua staff mempunyai standard knowledge yang sama mengenai We Act ini. Lalu sosialisasi kepada tamu, setiap tamu yang check-in pasti akan diinformasikan beberapa hal mengenai We Act contohnya bahwa air flush toilet kita adalah recycle water, lalu kami pun tidak lagi menggunakan air minum dengan kemasan, lalu jika tamu menginginkan bedsheetnya diganti tamu harus menaruh tent card yang bertulisan "bahwa jika ingin spreinya diganti harus meletakan tent card ini di atas kasur" hal ini dibuat untuk melangsungkan program save water and energy. Selain itu Video We Act yang kami buat pun kami display di Channel TV Hotel (channel 1), lalu TV di lobby dan juga TV di lift, untuk membuat para tamu juga aware akan "We Act" Ra Premiere Simatupang." (Daphne C. Angela, komunikasi pribadi, 30 April 2020)

Pernyataan di atas menjelaskan bahwa, divisi public relations telah menggunakan berbagai macam bentuk komunikasi untuk mempermudah publik yang ingin menggali informasi sekaligus menciptakan opini dan citra yang baik mengenai Hotel Ra Premiere Simatupang. Hal 
ini juga didukung dengan pernyataan dari narasumber ketiga yaitu tamu dari Hotel Ra Premiere Simatupang dalam penjelasannya mengenai bentuk komunikasi yang dilakukan oleh PR Hotel Ra Premiere Simatupang dalam mempublikasikan kampanye "We Act": "Nah Hotel Ra Premiere Simatupang Jakarta ini juga mengkampanyekan kegiatannya tersebut secara internal dan eksternal. Kalau aku lihat dari instagramnya tuh aku suka, aku follow juga instagramnya mereka, itu mereka dengan jelas memaparkan apa saja sih inisiatif-inisiatif yang mereka miliki dalam bentuk video campaign mereka." (Herryn, komunikasi pribadi, 22 April 2020)

Dalam hal itu tentu sudah sangat jelas dapat disimpulkan bahwa peran public relations sangat penting untuk memberikan persepsi yang baik dalam kampanye "We Act" di Hotel Ra Premiere Simatupang. Persepsi yang diberikan narasumber ketiga menjadi salah satu poin utama public relations dalam menjadi communicator. Sehingga persepsi yang baik akan menimbulkan citra yang baik juga, karena menurut Dewney citra adalah impresi mengenai perusahaan yang ada dalam benak konsumen. Oleh karena itu pemberian informasi yang tidak tepat akan menimbulkan impresi yang salah atau buruk dan mengakibatkan citra yang terbentuk juga buruk. (Soemirat, S. \& Ardianto, 2012)

\section{Membina Relationship}

Menurut Fawkes (dalam Theaker, A. \& Yaxley, 2013, p.18) mengatakan bahwa kegiatan yang dilakukan untuk membina hubungan yang harmonis dan saling menguntungkan kedua belah pihak. Tentu sangatlah penting bagi divisi Public Relations untuk selalu menjaga dan membina hubungan baik antar internal maupun eksternal dengan melakukan kegiatan-kegiatan yang berkaitan dengan Public Relations dengan publik internal dan publik eksternal Hotel Ra Premiere Simatupang. "Contoh singkat hubungan PR dengan publik internal adalah seperti memberikan informasi mengenai ongoing program, lalu berkordinasi dengan department lain untuk tetap menjalin hubungan yang baik dengan para client, supplier, sponsor dll. Mengarahkan setiap personel dari masing-masing department mengenai bagaimana cara berkomunikasi yang baik untuk mempertahankan kerjasama dengan pihak eksternal. Dengan publik eksternal, PR harus mampu membaca trend sehingga segala jenis promo atau campaign yang dijalankan dapat sampai pesannya kepada benak setiap customer atau setiap eksternal yang dituju." (Daphne C. Angela, komunikasi pribadi, 30 April 2020)

Pernyataan diatas menjelaskan bahwa yang sudah dilakukan oleh public relations Hotel Ra Premiere Simatupang adalah memberikan informasi yang akurat, dalam hal ini mensosialisasikan kampanye "We Act" kepada seluruh publik internal dan eksternal Hotel Ra Premiere Simatupang. Tentunya hal ini didasari dengan alasan dan tujuan dari public relations Hotel Ra Premiere Simatupang. Hal tersebut juga diperkuat melalui pernyataan atau kesan dirasakan oleh narasumber keempat yaitu publik eksternal atau tamu dari Hotel Ra Premiere Simatupang selama menginap di Hotel Ra Premiere Simatupang dalam penjelasannya : "Saya merasa amaze karena jarang sekali saya temukan di beberapa hotel lainnya yang concern terhadap lingkungan disekitarnya seperti hotel Ra Premiere Simatupang ini, juga dalam menggunakan fasilitas-fasilitasnya saya merasa lebih aman dan nyaman, selain itu secara tidak langsung saya juga dapat membantu dan mendukung gerakan melestarikan lingkungan yang ada melalui kampanye "We Act" ini." (Aji Mas Fitra, komunikasi pribadi, 20 Mei 2020)

Pernyataan di atas menjelaskan bahwa alasan divisi public relations Hotel Ra Premiere Simatupang turut andil dalam kampanye "We Act" yaitu untuk membuat Hotel Ra Premiere Simatupang menjadi lebih concern terhadap lingkungan sekitar, dan juga sebagai menjaga relationship antara divisi public relations Hotel Ra Premiere Simatupang dengan publik internal dan eksternalnya. Sehingga dengan adanya kampanye tersebut yang dilakukan secara 
terus-menerus dan rutin, akan membuat citra Hotel Ra Premiere Simatupang semakin meningkat.

\section{Back Up Management}

PR menunjang kegiatan planning, organizing, actuating, controling untuk mencapai tujuan perusahaan. Bentuk dukungan yang dilakukan oleh public relations Hotel Ra Premiere Simatupang dalam menjalankan kampanye "We Act" dapat disebut sebagai bentuk back up management dari seorang public relations yaitu melaksanakan dukungan manajemen, seperti manajemen promosi, pemasaran, operasional, personalia, dan sebagainya guna mencapai tujuan bersama dalam suatu kerangka tujuan pokok perusahaan / organisasi. (Ruslan, 2016, p.26) "Tentu dukungan yang dilakukan PR selama menjalankan campaign ini adalah seperti distribusi press release, lalu exposure melalui media cetak, sosial media, celebrity/celebgram review (endorsement)." (Daphne C. Angela, komunikasi pribadi, 30 April 2020)

Hal tersebut juga didukung oleh pernyataan dari narasumber pertama yaitu chief operating officer dari Hotel Ra Premiere Simatupang yang menyatakan bahwa public relations Hotel Ra Premiere Simatupang konsisten dalam melakukan publikasi kepada publik internal dan eksternal baik sebelum dan sesudah dilakukannya kampanye "We Act". "Karena We Act ini adalah sebuah gerakan yang baru, maka tentu belum sebesar atau sebanyak itu exposure yang tersebar di media, walaupun begitu usahapun tetap PR lakukan, seperti jika ada promo hotel atau pun release mengenai event hotel tak jarang kami selipkan sedikit mengenai bagaimana hotel kami menerapkan eco green." (Angkoso B. Soekadari, komunikasi pribadi, 12 Mei 2020)

Pernyataan di atas juga menjelaskan beberapa kelebihan dari bentuk dukungan yang diberikan oleh divisi public relations Hotel Ra Premiere Simatupang dalam menjalankan kampanye "We Act" diantaranya PR menyelipkan sedikit informasi mengenai bagaimana hotel Ra Premiere Simatupang dalam menerapkan eco green pada saat terdapat promo hotel atau pun release mengenai event hotel.

\section{Proses Membentuk Citra Hotel Ra Premiere Simatupang / Good Image Maker}

Image : the impression, the feeling, the conception which the public has of a company, a consciously created impression of an object, person or organization. (Soemirat, S. \& Ardianto, 2012, p.111)

Jika di terjemahkan citra adalah suatu impresi atau kesan, perasaan, gambaran diri publik terhadap perusahaan, kesan yang dengan sengaja diciptakan dari suatu obyek, orang atau organisasi. Sehingga dapat disimpulkan dengan kesan yang dihasilkan secara baik, akan menimbulkan citra yang baik. PR Hotel Ra Premiere Simatupang berupaya menciptakan citra bagi Hotel Ra Premiere Simatupang dengan sikap favoritiable, good will, mutual confidence salah satunya dalam aktivitas kampanye "We Act". "Sering kali kami mendapatkan positive feedback dari para tamu kami, baik tamu yang melakukan reservasi melalui online travel agent, atau tamu dari corporate. Respon baik dan respon excited mereka sudah menjadi good sign atau sudah mewakili bahwa We Act ini adalah sebuah program yang terpuji, yang juga bisa kami anggap sebagai UNIQUE SELLING POINT kami. Banyak tamu yang posting di instagram mereka mengenai We Act ini, begitu bangganya mereka melihat bahwa ada hotel di tengah-tengah Cilandak yang sangat concern mengenai eco living, kamipun sering menerima pujian melalui review di OTA (Online Travel Agent), review di agoda, tripadvisor, traveloka dan yang lainnya. Bisa dilihat juga dari ranking yang diberikan oleh OTA tersebut untuk hotel kami, dan ranking tersebut setiap tahun semakin meningkat." (Daphne C. Angela, komunikasi pribadi, 30 April 2020) 
Adanya peningkatan citra yang terbentuk setelah dilakukannya kampanye "We Act", perubahan citra yang terjadi dari Hotel Ra Premiere Simatupang ini tak lain adalah karena banyaknya positif feedback yang diberikan oleh para tamu Hotel Ra Premiere Simatupang baik dari tamu yang melakukan reservasi melalui online travel agent maupun tamu dari corporate, yang dibuktikan dengan banyaknya tamu yang posting di instagram mereka mengenai kampanye We Act. Dapat dilihat juga dari ranking yang diberikan oleh berbagai OTA (agoda, tripadvisor, traveloka dan yang lainnya) terhadap Hotel Ra Premiere Simatupang, dan ranking tersebut yang semakin meningkat setiap tahunnya. Dengan adanya kampanye tersebut yang dilakukan secara terus-menerus maka peran public relations berhasil dalam membentuk citra dilihat dari adanya peningkatan ranking di berbagai OTA karena banyaknya pujian yang diberikan oleh tamu kepada Hotel Ra Premiere Simatupang melalui review di OTA.

Tak hanya itu narasumber ke-empat juga menyatakan citra Hotel Ra Premiere Simatupang yang semakin berkembang sebagai hotel yang eco friendly dan mementingkan lingkungan sekitarnya, seperti pada penjelasan berikut : "Sebelum saya mengetahui adanya kampanye "We Act" ini, citra hotel Ra Premiere Simatupang dimata saya pribadi memang sudah sebagai green hotel karena konsep hotelnya sendiri yang memang sudah terlihat hijau banget gitu dimulai dari lobby, kamar, bahkan sampai terasnya sendiri yang diisi oleh banyak tumbuhan disekitarnya. Dan setelah saya mengetahui bahwa hotel Ra Premiere Simatupang memiliki program kampanye "We Act" yang didalamnya terdapat beberapa inisiatif-inisiatif yang dimiliki hotel untuk melestarikan lingkungan dan dapat sangat membantu dalam menyelamati bumi kita yang sudah semakin tua ini, citra hotel Ra Premiere Simatupang dimata saya pribadi semakin berkembang sebagai hotel yang eco friendly dan sangat mementingkan lingkungan disekitarnya." (Aji Mas Fitra, komunikasi pribadi, 20 Mei 2020)

Hal ini juga satu suara dengan pernyataan narasumber ketiga yang juga merupakan tamu dari Hotel Ra Premiere Simatupang menyatakan sebagai berikut: "Sebelumnya malah belum pernah dengar yang namanya ada hotel Ra Premiere Simatupang, karena lumayan cukup asing jadi aku kurang tau bagaimana citra dari hotel Ra Premiere Simatupang sebelum adanya kampenye "We Act" ini. Dan to be honest setelah aku nginap disana aku amaze, menurut aku sih citranya mereka tuh cukup berkembang sih, mereka punya kampanye "We Act" ini selain aktif di internal, mereka juga aktif di eksternal. Karena terlihat mereka bener-bener pakai sosial medianya dengan sebaik mungkin kalau menurut aku." (Herryn, komunikasi pribadi, 22 April 2020) Pada pernyataan di atas, menunjukan bahwa adanya persamaan persepsi yang ingin diciptakan oleh kedua publik baik internal maupun eksternal, yaitu divisi public relations dan tamu Hotel Ra Premiere Simatupang.

Berdasarkan hasil analisa yang didapat mengenai peran public relations yang dilakukan divisi public relations dari Hotel Ra Premiere Simatupang, peneliti telah melakukan analisa keempat narasumber yang memiliki pengalaman dan informasi yang berkaitan dengan kampanye public relations "We Act" Hotel Ra Premiere Simatupang menunjukan bahwa secara bertahap citra Hotel Ra Premiere Simatupang terbentuk, dari citra awal yang hanya dikenal sebagai green hotel hanya karena terlihat dari konsep hotelnya saja yang hijau karena diisi oleh banyak tumbuhan disekitarnya, secara perlahan semakin berkembang menjadi hotel yang eco friendly dan sangat mementingkan lingkungan disekitarnya karena Hotel Ra Premiere Simatupang menunjukan perhatiannya yang lebih mengenai eco living melalui kampanye public relations "We Act" ini. Hal ini menunjukan bahwa implementasi dari kampanye ini sangat langsung berdampak dengan citra yang terbentuk secara perlahan dari Hotel Ra Premiere Simatupang.

Menurut Pfau dan Parrot yang dikutip dari Venus (2018, p.10) dalam buku manajemen kampanye panduan teoritis dan praktis dalam mengefektifkan kampanye komunikasi public 
edisi revisi, menyebutkan tiga istilah efek dalam kampanye yang dapat mencapai khalayak sasaran kampanye, yakni sebagai berikut :

\section{- Awareness}

Pengaruh yang diharapkan dalam tahapan ini adalah munculnya kesadaran, berubahnya keyakinan atau meningkatnya pengetahuan para tamu atau karyawan Hotel Ra Premiere Simatupang mengenai isu yang diangkat pada kampanye "We Act". "Dimulai dari kolam renang yang tidak menggunakan air kaporit tetapi memakai air garam, Hotel Ra Premiere Simatupang Jakarta justru memikirkan kesehatan tamu-tamunya gitu. Jadi untuk kesehatan di kulit juga, ... " (Herryn, komunikasi pribadi, 22 April 2020) Pada pernyataan tersebut, menunjukan bahwa adanya peningkatan pengetahuan tamu Hotel Ra Premiere Simatupang dalam hal penelitian ini mengenai salah satu isu yang diangkat pada kampanye "We Act".

\section{- Attitude}

Untuk menumbuhkan rasa simpati, rasa suka, kepedulian atau keberpihakan tamu atau karyawan Hotel Ra Premiere Simatupang terhadap isu-isu yang menjadi tema kampanye "We Act". "Saya merasa amaze karena jarang sekali saya temukan di beberapa hotel lainnya yang concern terhadap lingkungan disekitarnya seperti Hotel Ra Premiere Simatupang ini, juga dalam menggunakan fasilitas-fasilitasnya saya merasa lebih aman dan nyaman, selain itu secara tidak langsung saya juga dapat membantu dan mendukung gerakan melestarikan lingkungan yang ada melalui kampanye "We Act" ini." (Aji Mas Fitra, komunikasi pribadi, 20 Mei 2020) Pernyataan tersebut dapat mendukung efek kampanye public relations pada tahapan attitude ini, bahwa tamu tersebut telah menunjukan kepedulian atau keberpihakannya terhadap kampanye "We Act" Hotel Ra Premiere Simatupang dengan cara membantu dan mendukung gerakan melestarikan lingkungan yang ada melalui kampanye "We Act" ini.

\section{- Action}

Tahapan ini menghendaki adanya tindakan tertentu yang dilakukan oleh tamu atau karyawan Hotel Ra Premiere Simatupang. Dalam hal penelitian ini, tamu atau karyawan dari Hotel Ra Premiere Simatupang telah menunjukan action-nya dalam mengubah perilaku mereka menjadi lebih peduli terhadap lingkungan sekitar dengan sangat mendukung dan menerapkan inisiatif-inisiatif yang ada dalam program kampanye "We Act" Hotel Ra Premiere Simatupang.

Berdasarkan model pembentukkan citra yang berbentuk kerangka konseptual, yang disusun untuk melihat bagaimana cara proses pembentukan citra dengan menggunakan pendekatan Model Pembentukan Citra yang dijelaskan oleh Lipman (dalam Soemirat, S. \& Ardianto, 2012, p.114) dalam struktur kognitif, dalam laporan penelitian tentang Tingkah Laku Konsumen yang dikutip Danasaputra sebagai berikut :

- Persepsi

Langkah yang dilakukan Hotel Ra Premiere Simatupang dalam membentuk citranya yakni dengan membuat program Kampanye Public Relations "We Act", kampanye ini merupakan suatu bentuk program yang dijalankan oleh Hotel Ra Premiere Simatupang dimana dalam komunikasi kampanye mengandung pesan himbauan atau ajakan yang tujuannya menumbuhkan kesadaran masyarakat terhadap kepedulian akan lingkungan. Melalui kampanye "We Act" tersebut Hotel Ra Premiere Simatupang ingin membentuk citranya sebagai hotel yang ramah lingkungan (green hotel) dan mempraktikkan penghematan energi. 


\section{- Kognisi}

Public Relations Hotel Ra Premiere Simatupang Jakarta senantiasa menjaga dan membina hubungan yang baik dengan media dalam penyebaran informasi, dan public relations juga rutin dalam membawakan informasi terkait kegiatan kampanye "We Act" di media sosialnya, sehingga mempermudah publik untuk mendapatkan informasi mengenai kegiatan ini.

Adanya media internal yang mempublikasikan kegiatan kampanye "We Act" adalah Channel TV Hotel (channel 1), TV di lobby, juga TV di lift, dan media sosial seperti Instagram serta website Hotel Ra Premiere Simatupang untuk membuat para tamu lebih aware akan kampanye "We Act" Ra Premiere Simatupang.

\section{- Motivasi}

Sebagai motivasi untuk para tamu dan karyawan, public relations terus mengoptimalkan kepeduliannya dalam melestarikan lingkungan yang ada melalui kampanye "We Act". Dalam penelitian ini para tamu dan karyawan dapat menjadi motivasi bagi seluruh komponen di dalam Hotel Ra Premiere Simatupang. Banyaknya tamu yang turut andil dan mendukung program kampanye "We Act" dapat menjadi pencapaian bagi Hotel Ra Premiere Simatupang, bahwa Hotel Ra Premiere Simatupang menjadi dikenal sebagai hotel di daerah Jakarta Selatan yang sangat concern mengenai eco living.

- Sikap

Sikap merupakan suatu hal yang sangat penting dalam pembentukan suatu citra perusahaan, karena pada akhirnya sikap yang akan menjadi acuan perusahaan mengenai pro dan kontra segala bentuk kegiatan atau strategi yang diadakan di Hotel Ra Premiere Simatupang. Maka dengan membuat program Kampanye Public Relations "We Act", mereka selalu memberikan konsistensi dalam pelayanan terbaik untuk selalu melayani dengan penuh semangat dan kesabaran untuk terus mengingatkan kepedulian terhadap lingkungan kepada seluruh tamu dan karyawan di Hotel Ra Premiere Simatupang Jakarta.

\section{PENUTUP}

Dalam melakukan peran sebagai Public Relations dari institusi tertentu, dibutuhkan beberapa upaya yang harus dilakukan guna mencapai tujuan yang diharapkan. Penelitian ini berfokus pada peran Public Relations dari divisi public relations Hotel Ra Premiere Simatupang. Mengacu pada empat peran Public Relations menurut Rosady Ruslan, terdapat satu peran yang peneliti rasa belum dapat dikerjakan secara maksimal yakni Back Up Management, dimana kurangnya intensitas yang tinggi kepada publik internal atau karyawan, yang terkadang masih tidak konsisten dalam mendukung jalannya kampanye "We Act" dikarenakan sulitnya menjangkau publik internal secara keseluruhan melalui media kampanye karena departemen yang ada di Hotel Ra Premiere Simatupang cukup banyak. Peneliti memberikan saran agar selalu berinovasi terhadap perkembangan teknologi yang dapat memudahkan Hotel Ra Premiere Simatupang menjangkau publik internal.

\section{DAFTAR PUSTAKA}

Amalya, R. (2015). Strategi Kampanye Public Relations Listrik Pintar PT PLN (Persero) Wilayah Riau dan Kepulauan Riau dalam Mewujudkan Smart Consumer di Pekanbaru. Jurnal Online Mahasiswa (JOM) Universitas Riau, 2, 5. https://media.neliti.com/media/publications/32429-ID-strategi-strategistrategi-strategi-strategi-strategi-kampanye-kampanye-kampanye.pdf 
Ardianto, E. (2011). Handbook of Public Relations. Pengantar Komprehensif. Remaja Rosdakarya.

Ardianto, E. (2016). Metodologi Penelitian Untuk Public Relations: Kuantitatif dan Kualitatif. Simbiosa Rekatama Media.

BPS Jakarta. (2018). Statistik Hotel dan Tingkat Penghunian Kamar Hotel 2018.

Daud, R. F., \& Apriliani, D. (2017). Kampanye Public Relations Partai Nasional Demokrat (NASDEM) melalui Sosialisasi Program Kampung Enterpreneur Creative (KECE) untuk Meningkatkan Kesejahteraan Ekonomi. Jurnal Analisis Sosial Politik, 249262.

Haningtyas, A. (2018). Peran Public Relations Dalam Meningkatkan Citra Hotel Sahid Melalui Event Yoga. Jurnal Riset Komunikasi, 1, 9. https://doi.org/10.24329/jurkom.v1i2.31

Ikeda, K., \& Marshall, A. (2016). How successful organizations drive innovation. Strategy and Leadership. 9-19.

Kencana, B., Agustina, I., Panjaitan, R., \& Sulistiyanto, R. (2015). Panduan Praktis Penghematan Energi di Hotel. Iced Project.

Keuangan, K. (n.d.). Undang-Undang Republik Indonesia Nomor 10 Tahun 2009 Tentang Kepariwisataan.

https://jdih.kemenkeu.go.id/fullText/2009/10TAHUN2009UU.HTM

Roedji, N. R. (2016). Hotel Hijau Sebagai Alternatif Pengurangan Dampak Lingkungan. Jurnal Pariwisata Pesona, 18.

Ruslan, R. (2016). Manajemen Public Relations dan Media Komunikasi: Konsepsi dan Aplikasi Edisi Revisi. PT Raja Grafindo Persada.

Sinangjoyo, N. J. (2013). Green Hotel Sebagai Daya Saing Suatu Destinasi. Jurnal Nasional Pariwisata, 5.

Soemirat, S. \& Ardianto, E. (2012). Dasar-dasar Public Relations. PT Remaja Rosdakarya.

Supriadi, B. (2016). Investigasi Green Hotel Sebagai Alternatif Produk Ramah Lingkungan. Prosiding SENIATI.

Theaker, A. \& Yaxley, H. (2013). The Public Relations handbook. Routledge.

Venus, A. (2018). Manajemen Kampanye Panduan Teoritis Dan Praktis Dalam Mengefektifkan Kampanye Komunikasi Publik Edisi Revisi. Simbiosa Rekatama Media. 